\title{
Glomalin-Related Soil Protein Content in Areas of Degraded and Revegetated Caatinga in the Municipality of Irauçuba
}

\author{
Cillas Pollicarto Silva ${ }^{1}$, Paulo Furtado Mende Filho ${ }^{1}$, Vânia Felipe Freire Gomes ${ }^{1}$, Claudia Miranda Martins ${ }^{1}$, \\ Cleyton Saialy Medeiros Cunha ${ }^{1} \&$ Márcio Godofrêdo Rocha Lobato ${ }^{1}$ \\ ${ }^{1}$ Universidade Federal do Ceará, Fortaleza, CE, Brazil \\ Correspondence: Cillas Pollicarto Silva, Universidade Federal do Ceará, Fortaleza, CE, Brazil. E-mail: \\ cillaspollicarto@hotmail.com
}

Received: September 18, 2017

Accepted: November 9, 2017 Online Published: December 15, 2017

doi:10.5539/jas.v10n1p302

URL: https://doi.org/10.5539/jas.v10n1p302

\begin{abstract}
Anthropic activities, combined with the natural ones, may trigger soil degradation, which has increased day by day and contributed to accentuating the desertification processes, resulting in losses of biodiversity and fertility of the soils. Because of that, the utilization of tools that indicate the stages of such degradation and recovery becomes necessary, in order to make viable and adequate management of these areas. Thus, the study on arbuscular mycorrhizal fungi (AMF), as a perspective to facilitate the recovery of degraded areas has increased, especially for the production of glomalin-related soil protein, which is of great importance for aggregate stability, besides showing a great potential of utilization as soil quality indicator. Therefore, the present study aimed to evaluate the contents of glomalin-related soil protein, correlating with chemical, physical and biological attributes in areas of the municipality of Irauçuba-CE: area degraded by overgrazing, area under process of natural revegetation managed with the exclusion of domestic animals and area of native forest, characterized by tree-shrub Caatinga vegetation. Disturbed soil samples were collected in the layer of $0-10 \mathrm{~cm}$ in each area and evaluated for AMF attributes, soil chemical attributes and physical attributes. The results obtained with the tests of means prove that, among the three areas, only the native forest showed significant differences with respect to both fractions of the protein. However, in regard to spore density and aggregate stability, the areas of native forest and exclusion showed the best mean values. The content glomalin-related soil protein (GRPS), associated with other edaphic attributes, contributes to discriminating the quality and to the monitoring of areas with different levels of soil degradation. The highest correlation values were observed among the contents of calcium, nitrogen and organic carbon and both GRSP fractions (easily extractable: GRSP ${ }_{\mathrm{EE}}$, which represents the recently deposited frsction that has not yet suffered biochemical alterations in the soil; total: $\mathrm{GRSP}_{\mathrm{T}}$, which is strongly adhered to the clays), indicating that the protein directly influences the contents of these elements in the soil.
\end{abstract}

Keywords: arbuscular mycorrhizal fungi, degraded area, glycoprotein

\section{Introduction}

The removal of natural vegetation, combined with long drought periods in the semi-arid regions of Northeast Brazil, lead to physical, chemical and biological modifications in the system, causing a severe increase in soil degradation, compromising the edaphic microbiota and the natural regeneration of the native species (Batista et al., 2009; Silva et al., 2010). The municipality of Irauçuba, located in the Ceará state, has climatic, geological and geomorphological conditions in the soils and vegetation that reflect well the typical characteristics of the semi-arid regions (Sousa, 2009). Extensive livestock farming under overgrazing conditions has caused soil degradation, since it involves the removal of the pre-existing vegetation, increasing the risk of erosion, favoring soil compaction by trampling, reducing porosity, density and, additionally, leading to damages in the water infiltration rate in the soil (Pei et al., 2008).

Studies to make viable the understanding on the physical, chemical and biological aspects of these soils are conducted in such a way to facilitate the comprehension and management of these degraded areas (Sousa et al., 2012a). The studies are conducted in areas under conditions of exclusion of animals, which according to some authors is a management technique that has been considered as a valid tool in the recovery of lands that have not yet been completely degraded (Mekuria et al., 2007; Lipper et al., 2010). 
Among the physical, chemical and biological aspects, the biotic components of the soil, especially the arbuscular mycorrhizal fungi (AMF), represent one of the main constituents of the edaphic microbiota that helps in the processes of recovery of the degraded areas, contributing to the aggregation state of eroded soils and thus reducing the risks in the advance of degradation in more-susceptible areas (Schneidr et al., 2011). Previous studies emphasize that the importance of the AMF results not only from the mechanical effect of the hyphae, but also from the production of a substance called glomalin, which stands out for constituting an important component of the stock of carbon and nitrogen of the soil and for assisting in the protection of fungal hyphae from desiccation and in the aggregation of mineral and organic particles present in the soil (Barto et al., 2010; Lovelock et al., 2004; Nobre et al., 2015; Peng et al., 2013).

Glomalin, also known as glomalin-related soil protein (GRSP), is a glycoprotein that is hydrophobic, thermostable and recalcitrant, produced by the decomposition of AMF hyphae and spores (Sousa et al., 2012b). Generally, there are two types of GRSP: easily extractable $\left(\mathrm{GRSP}_{\mathrm{EE}}\right)$, which represents the recently deposited fraction that has not yet suffered biochemical alterations in the soil; and total $\left(\mathrm{GRSP}_{\mathrm{T}}\right)$, which is strongly adhered to the clays (Wright et al., 1996; Wright \& Upadhyaya, 1998).

Various studies demonstrate that the GRSP contents have been affected by the changes in land use (López-Merino et al., 2015; Loss et al., 2009; Souza et al., 2010). Considering that the higher the GRSP content, the better the soil quality and that, for exhibiting close correlations with the main soil quality attributes (Purin, 2005; Vaidya et al., 2011), the production of these proteins by the glomalean fungi can be considered as a reinforcement in the indication of soil quality, an aspect still little considered in the evaluation of degradation.

\section{Material and Methods}

\subsection{Location of the Studied Area}

The study was carried out in the experimental area of the project "Estudos dos processos de Degradação/Desertificação e suas relações com o uso da terra em Sistemas de Produção no Semiárido cearense: O caso da microrregião de Sobral, Ceará". The area is located on the Formigueiro Farm in the municipality of Irauçuba (Figure 1) in the Mid-North Sertão region of the Ceará state, in the microregion of Sobral, at the coordinates of $03^{\circ} 46^{\prime} 50^{\prime \prime} \mathrm{S}$ and $39^{\circ} 49^{\prime} 03^{\prime \prime} \mathrm{W}$. The municipality has an area of $1,451 \mathrm{~km}^{2}$, with altitude of 152.5 $\mathrm{m}$. The climate of the region is semi-arid, with mean annual temperature and rainfall of $26.3{ }^{\circ} \mathrm{C}$ and $530 \mathrm{~mm}$, respectively, basically concentrated in three months of the year.

A

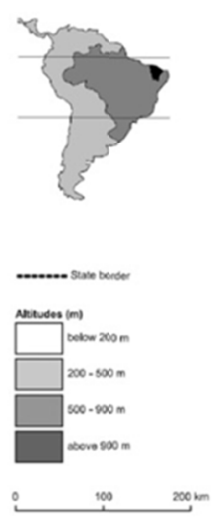

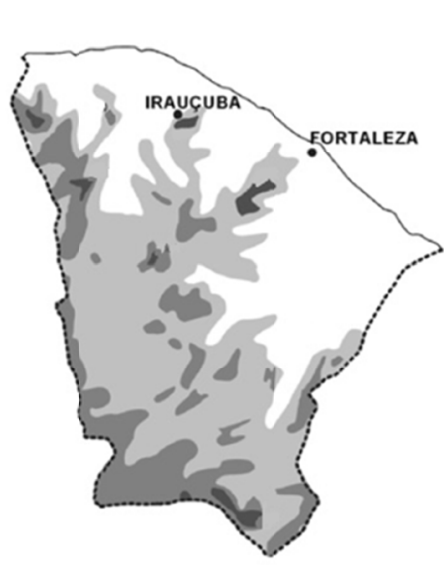

B

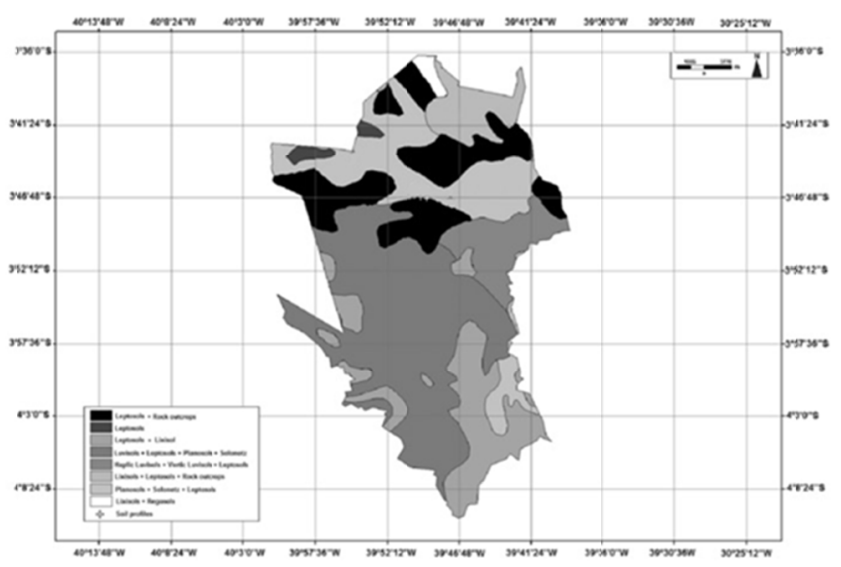

Figure 1. Brazil, Ceará state and the location of the studied area in the rural district of Irauçuba (A), along with the soil survey map of the Irauçuba zone indicating the current associations of soils (B)

\subsection{Fieldwork}

Soil samples were collected at the end of February 2014, in three areas, all areas with native tree caatinga (mainly black jurema - Mimosa hostilis): one area was subjected to exclusion of grazing, which has been fenced for more than 10 years to avoid grazing by cattle, sheep, goats, horses, donkeys, mules and for the evaluation of 
natural regeneration processes; another area was subjected to overgrazing, consisting in areas of free access by the animals, used to evaluate the influence of overgrazing over time; and an area under native forest located beside the studied areas and used as a control. Each area has 0.25 hectare and in each one of them 07 soil samples of 1 kilogram each were collected, these samples were manually collected with shovel and conditioned in plastic bags. The samples were collected randomly, passing georeferenced zigzag to a depth of $0-10 \mathrm{~cm}$, and each sample was considered a replication. After collection, the samples were pre-dried in the shade, placed in plastic bags and stored at $10{ }^{\circ} \mathrm{C}$.

\subsection{Soil Physical Analyses}

The following physical analyses (Table 1) were performed: aggregate stability, through the wet sieving method, whose principle is to measure the amount and distribution of the size of the aggregates that are stable in water, relating them with those that do not disintegrate by sieving; and granulometric analysis, determined through the pipette method (Gee \& Bauder, 1986), with dispersion of $20 \mathrm{~g}$ of air-dried fine earth (ADFE) using $1 \mathrm{~mol} \mathrm{~L}^{-1}$ sodium hydroxide. The sands were separated in $0.053-\mathrm{mm}$-mesh sieves and fractioned according to the reference granulometric classification of the United States Department of Agriculture (USDA). Silt and clay were separated by sedimentation, according to the Stokes' law.

Table 1. Soil physical characteristics: granulometry and aggregate stability in three areas: overgrazing, exclusion and native forest in the municipality of Irauçuba-CE, 2015

\begin{tabular}{llllll}
\hline Areas/Treatments & Sand (\%) & Silt (\%) & Clay (\%) & AS (\%) & Classification \\
\hline Overgrazing & 77.87 & 10.01 & 12.12 & 74.43 & Sandy loam \\
Exclusion & 79.00 & 10.70 & 10.30 & 81.91 & Sandy loam \\
Native Forest & 68.54 & 15.14 & 16.32 & 85.43 & Sandy loam \\
\hline
\end{tabular}

Note. AS: aggregate stability.

\subsection{Soil Chemical Analyses}

The chemical analyses of the soil samples (Table 2) were conducted at the Soil-Water-Plant Laboratory of the Soil Sciences Department of the Federal University of Ceará (UFC), namely: pH (in $\mathrm{H}_{2} \mathrm{O}$ ), measured using a combined electrode immersed in soil suspension; potential acidity $\left(\mathrm{H}^{+} \mathrm{Al}^{3+}\right)$, obtained through extraction using buffered solution of calcium acetate at $\mathrm{pH} 7.0$; exchangeable aluminum $\left(\mathrm{Al}^{3+}\right)$, extracted with $\mathrm{KCl}$ solution and volumetrically determined with diluted $\mathrm{NaOH}$ solution; exchangeable bases $\left(\mathrm{Ca}^{2+}, \mathrm{Mg}^{2+}\right)$, determined by the $\mathrm{KCl}$ method; phosphorus (P-available), determined using an extracting solution $\left(0.05 \mathrm{~N} \mathrm{HCl}\right.$ and $\left.0.025 \mathrm{~N} \mathrm{H}_{2} \mathrm{SO}_{4}\right)$ and also a diluted acid solution of ammonia molybdate and ascorbic acid powder as reducer, with reading performed through photocolorimetry; organic matter (OM) and organic carbon $(\mathrm{OC})$, determined through oxidation of organic matter with potassium dichromate $\left(0.167 \mathrm{~N} \mathrm{~K}_{2} \mathrm{Cr}_{2}\right)$ in sulfuric medium $\left(\mathrm{H}_{2} \mathrm{SO}_{4}\right)$. The excess of dichromate, after oxidation, was titrated with $0.5 \mathrm{~N}$ solution of ammonium iron (II) sulfate $\left[\mathrm{Fe}\left(\mathrm{NH}_{4}\right)_{2}(\mathrm{SO}) \cdot 6 \mathrm{H}_{2} \mathrm{O}\right]$ in the presence of diphenylamine indicator with subsequent estimation of the organic matter content. All these methodologies are described by the Manual of Soil and Plant Analysis Methods of EMBRAPA (1997).

Table 2. Mean values of soil chemical attributes in the layer of $0-10 \mathrm{~cm}$ in areas of overgrazing, exclusion and native forest in the municipality of Irauçuba-CE, 2015

\begin{tabular}{llll}
\hline \multirow{2}{*}{ Chemical attributes } & \multicolumn{2}{c}{ Sampling areas } \\
\cline { 2 - 4 } & Overgrazing & Exclusion & Native Forest \\
\hline $\mathrm{pH}\left(\mathrm{H}_{2} \mathrm{O}\right)$ & 4.96 & 5.00 & 5.69 \\
$\mathrm{Ca}^{2+}\left(\mathrm{cmolc} \mathrm{kg}^{-1}\right)$ & 2.37 & 2.41 & 6.60 \\
$\mathrm{Mg}^{2+}\left(\mathrm{cmolc} \mathrm{kg}^{-1}\right)$ & 2.07 & 1.79 & 3.37 \\
$\mathrm{Al}^{3+}\left(\mathrm{cmolc} \mathrm{kg}^{-1}\right)$ & 0.21 & 0.37 & 0.10 \\
$\mathrm{H}^{+} \mathrm{Al}^{3+}\left(\mathrm{cmolc} \mathrm{kg}^{-1}\right)$ & 2.73 & 4.07 & 4.77 \\
$\mathrm{P}\left(\mathrm{mg} \mathrm{kg}^{-1}\right)$ & 66.18 & 85.60 & 18.41 \\
$\mathrm{OC}\left(\mathrm{g} \mathrm{kg}^{-1}\right)$ & 4.52 & 7.39 & 9.61 \\
$\mathrm{~N}\left(\mathrm{~g} \mathrm{~kg}^{-1}\right)$ & 0.64 & 0.77 & 1.09 \\
$\mathrm{OM}\left(\mathrm{g} \mathrm{kg}^{-1}\right)$ & 7.78 & 12.70 & 16.53 \\
\hline
\end{tabular}




\subsection{Spore Density}

One hundred $g$ of soil were removed from the seven samples of each area for the extraction of AMF spores, following the technique of wet sieving (Gerdermann \& Nicolson, 1963). A set of overlapping sieves (with mesh of $850,250,100$ and $45 \mu \mathrm{m}$ ) was used to extract the total glomerospores. Then, the spores were quantified on a slide with channels using an optical stereoscopic microscope $(40 \times)$.

\subsection{Extraction and Quantification of Glomalin-Related Soil Protein (GRSP)}

GRSP was extracted through the method proposed by Wright and Upadhyaya (1998), which extracts the following GRSP fractions: easily extractable GRSP - GRSP $\mathrm{EE}_{\mathrm{EE}}$, obtained through the sequential extraction in autoclave, adding $1 \mathrm{~g}$ of soil in $8 \mathrm{~mL}$ of $20 \mathrm{mM}$ sodium citrate buffer solution $\left(\mathrm{pH} \mathrm{7.0)}\right.$ ), at temperature of $121{ }^{\circ} \mathrm{C}$ for $30 \mathrm{~min}$, and total GRSP - $\mathrm{GRSP}_{\mathrm{T}}$, obtained through sequential extraction using $1 \mathrm{~g}$ of soil added to $8 \mathrm{~mL}$ of a 50-mM sodium citrate buffer solution $\left(\mathrm{pH} \mathrm{8.0)}\right.$ at $121{ }^{\circ} \mathrm{C}$, for $60 \mathrm{~min}$. Both fractions, after autoclaving, underwent centrifugations at $10000 \times \mathrm{g}$ for $5 \mathrm{~min}$, and the supernatant was removed for later quantification of the protein. GRSP quantification was performed according to the method of Bradford (1976), using the bovine serum albumin protein as standard. GRSP was quantified using an absorbance measurement device (spectrophotometer). The contents of both GRSP fractions were corrected to $\mathrm{mg} \mathrm{g}^{-1}$ of soil, considering the total volume of supernatant and the soil dry weight. It is important to note that the Bradford reactive fraction of the GRSP, as reported in this study, does not to represent glomalin, that is, the immunoreactive fraction of GRSP. Glomalin is quantified by the monoclonal antibody, MAb32B11 used in the enzyme-linked immunosorbent assay (ELISA) (Rosier et al., 2006). Consequently, the Bradford reactive values in this study probably not represent exactly the content of glomalin; however, there is a direct correlation between the Bradford-reactive and ELISA assays indicating the efficacy of the Bradford assay to provide an estimate of glomalin (Rosier et al., 2006).

\subsection{Statistical Analysis}

Descriptive statistical analysis was applied to the data through the comparison of means, using the software XLSTAT, free version (XLSTAT, 2014). In addition, data normality at 0.05 probability level was tested using the Shapiro-Wilk test (W) and the mean was tested by the Scott Knott test $(\mathrm{p}<0.01)$. Then, the data were analyzed using multivariate statistical tools through the canonical correlation analysis, adopting two sets: Set one (CI), variables related to chemical, physical and biological attributes $\left(\mathrm{pH}, \mathrm{Ca}^{2+}, \mathrm{Mg}^{2+}, \mathrm{Al}^{3+}, \mathrm{P}, \mathrm{OC}, \mathrm{N}, \mathrm{AS}, \mathrm{SD}\right)$, and Set two (CII), variables constituted of both GRSP fractions $\left(\mathrm{GRSP}_{\mathrm{EE}}\right.$ and $\left.\mathrm{GRSP}_{\mathrm{T}}\right)$. Multivariate analysis was conducted using the software Statistica ${ }^{\circledR}$, version 7.0.

\section{Results and Discussion}

\subsection{GRSP Fractions in the Three Areas: Overgrazing, Exclusion and Native Forest}

The highest mean values of GRSP $\mathrm{EE}_{\mathrm{EE}}$ and $\mathrm{GRSP}_{\mathrm{T}}$ were found in the native forest area (Table 3). In the areas of overgrazing and exclusion, there was no significant statistical difference between both GRSP fractions. Various authors suggest that the deposition of this protein in the soil mainly occurs by the decomposition of AMF hyphae and spores (Driver, Holben, \& Rilling, 2005). Rilling et al. (2003) proved that the GRSP contents are also related to the organic matter in the soil; the higher the contents of organic matter, the higher the GRSP contents. In the present study, the native forest area showed the highest mean values of spore density and organic matter, which possibly explains the highest GRSP contents in this area.

It should be pointed out that the areas of overgrazing and exclusion do not exhibit significant differences regarding the contents of both GRSP fractions (Table 3). However, it is important to highlight that, despite the lack of statistical significance, the area of overgrazing, compared with the area of exclusion, showed the lowest quantitative mean values of the contents of the GRSP fractions. Some authors claim that human activities such as the removal of natural vegetation and inadequate soil use associated with climatic factors, light intensity and temperature, compromise the development of AMF hyphae and spores that are responsible for GRSP production (Mergulhão, 2006; Cardozo, 2011). The studied area of overgrazing has little or no vegetation and a consequent process of degradation, with presence of laminar erosion and inserted in a context of adverse climatic conditions, which may have damaged the production of external mycelium in the soil, the main responsible for the synthesis of GRSP. It is important to remember that the area in question has been degraded by the superpastejo and has undergone the elimination of vegetation by means of anthropic actions for more than twenty years, nevertheless this area presented a reasonable number of spores. Taking into account that AMF are severely affected by degenerative changes imposed on ecosystems, a possible explanation for the number of spores found in the superpastejo area would be the high adaptability of this group of fungi to the adverse conditions of these areas. 
Other studies have also shown similar results in relation to the number of spores indegraded areas (Moreira-Souza \& Cardoso, 2002; Moreira-Souza et al., 2004; Carrenho et al., 2001).

Table 3. Contents of $\mathrm{GRSP}_{\mathrm{EE}}$ and $\mathrm{GRSP}_{\mathrm{T}}\left(\mathrm{mg} \mathrm{g}^{-1}\right.$ soil) in soil samples of degraded (Overgrazing), managed (Exclusion) and native forest areas in the municipality of Irauçuba-CE, 2015

\begin{tabular}{lll}
\hline Areas/Treatments & GRSP $_{\mathrm{EE}}$ & GRSP $_{\mathrm{T}}$ \\
\hline Overgrazing & $0.22 \mathrm{~b}$ & $0.18 \mathrm{~b}$ \\
Exclusion & $0.54 \mathrm{~b}$ & $0.44 \mathrm{~b}$ \\
Native forest & $0.93 \mathrm{a}$ & $0.83 \mathrm{a}$ \\
\hline
\end{tabular}

Note. $\mathrm{GRSP}_{\mathrm{EE}}=$ easily extractable protein; $\mathrm{GRSP}_{\mathrm{T}}=$ total protein. Means followed by the same letter in the column do not differ by Scott Knott test $(p<0.01)$.

It is important to note that the area of exclusion, for being under natural regeneration with a greater diversity of plant species and showing higher mean values of spore density and organic matter contents (Tables 2 and 4 ), in relation to the area of overgrazing, may have contributed to stimulating the occurrence of AMF and, consequently, increasing the deposition of this protein in the soil (Wright \& Upadhyaya, 1996).

\subsection{Aggregate Stability and Spore Density in the Three Areas: Overgrazing, Exclusion and Native Forest}

Comparing the three areas, only exclusion and native forest had almost similar mean values of aggregate stability, and these two areas obtained better percentages of stable aggregates in the soil (Table 4). According to some authors, the stability of soil aggregates is very sensitive to changes in the ecosystems and can be directly altered by the adopted soil management systems (Barto et al., 2010; Sousa, 2009). This fact can be observed in the present study in the area of overgrazing, which showed the lowest mean value of aggregate stability (Table 4), a result that may be attributed to the degradation level of this area.

Bird et al. (2002), comparing the aggregate stability between degraded and non-degraded area in the semi-arid region of New Mexico, USA, found that aggregate stability behaved according to the degradation level, being more stable in areas with greater natural cover, since the organic matter has high influence on soil aggregation.

In regard to spore density in the areas under overgrazing and exclusion, there was no significant statistical difference and these areas obtained the lowest mean values of spores compared with the native forest (Table 4). In the case of these two areas, the one under overgrazing remains under conditions of degradation, because it has little or no natural vegetation and severe presence of laminar erosion, while the area of exclusion, which was thought as a model of recovery of these degraded areas, exhibited very few significant variations in the typical vegetation along these years of fallow (less than 20 years) (Valone \& Sauter, 2005; Pei et al., 2008; Zhao et al., 2007). The occurrence of a high number of spores found in the area of overgrazing may be related to the presence of grasses, as well as to the more stressful condition of this environment, causing the AMF to produce a high number of propagules in order to survive, although it is verified that most stresses reduce sporulation (Sylvia \& Jarstfer, 1992). Other authors have observed a smaller number of spores in soils with native vegetation in relation to agrosystems with anthropic influence. These authors attribute this pattern to the greater stability of the ecosystem, with more protected surface horizons against sudden disturbances, as well as, a smaller competition for niches, guaranteeing a survival of the species with low sporulation (Caproni et al., 2003).

Table 4. Aggregate stability (AS) and spore density (SD) in soil samples of degraded (Overgrazing), managed (Exclusion) and native forest areas in the municipality of Irauçuba-CE, 2015

\begin{tabular}{lll}
\hline Areas/Treatments & AS (\%) & SD (100 mL/soil) \\
\hline Overgrazing & $74 \mathrm{~b}$ & $4269 \mathrm{~b}$ \\
Exclusion & $82 \mathrm{a}$ & $5031 \mathrm{~b}$ \\
Native forest & $85 \mathrm{a}$ & $7833 \mathrm{a}$ \\
\hline
\end{tabular}

Note. AS = aggregate stability; $\mathrm{SD}=$ spore density. Means followed by the same letter in the column do not differ by Scott Knott test $(p<0.01)$.

According to McLellan et al. (1995), the propagules of AMF have close link with the processes related to the degradation of the lands that occur in various regions of the world, being severely affected when the soil-plant 
interaction suffers the action of environmental imbalance. However, Sylvia and Williams (1992) highlight that a more stressful condition of the environment causes the AFM possibly produces a large number of propagules to survive, a fact not very common, however corroborated with the present study where the native forest had a high number of spores. This is already expected, since these areas are located in the caatinga, which is a unique biome in the world, characterized by the formation of dry forest composed of xerophilous vegetation of arboreal, shrub and herbaceous, with wide variation of physiognomy and flora and high diversity of species, predominating representatives of Caesalpinaceae, Mimosaceae, Euphorbiaceae, Fabaceae and Cactaceae (Drumond et al., 2000). This caatinga area of the present study is today in accented process of desertification, caused, mainly, by deforestation and inadequate use. It is therefore possible that this stressful environment has induced sporulation as a form of survival and consequently conferred an increase in the number of spores (Franke \& Morton, 1994).

3.3 Multivariate Analysis: Canonical Correlations of Chemical, Physical and Biological Attributes with the GRSP Fractions

Table 5 shows the correlations and canonical pairs between physical, chemical and biological attributes related to the contents of both GRSP fractions $\left(\mathrm{GRSP}_{\mathrm{EE}}\right.$ and $\mathrm{GRSP}_{\mathrm{T}}$ ), in three distinct areas (overgrazing, exclusion and native forest) in Irauçuba-CE. For the first pair, the canonical correlations were highly significant $(0.01$ probability level) by the chi-square test (0.97). Hence, the set CI explains the set CII, in the first canonical pair, thus being of interest for the study. Among the variables related to the contents of both GRSP fractions, the attributes that most contributed to explaining the contents of the GRSP fractions in the soil were $\mathrm{Ca}^{2+}(\mathrm{R}=0.86)$, $\mathrm{N}(\mathrm{R}=0.84), \mathrm{OC}(\mathrm{R}=0.84), \mathrm{Mg}^{2+}(\mathrm{R}=0.71), \mathrm{pH}(\mathrm{R}=0.70)$ and $\mathrm{AS}(\mathrm{R}=0.61)$, respectively. In other words, as the values of $\mathrm{CI}$ increased, there is also an increase in the content of $\operatorname{GRSP}_{\mathrm{EE}}(\mathrm{R}=0.94)$ and $\operatorname{GRSP}_{\mathrm{T}}(\mathrm{R}=0.99)$; on the other hand, for the attributes $\mathrm{Al}^{3+}(\mathrm{R}=0.45), \mathrm{P}(\mathrm{R}=0.08)$ and $\mathrm{SD}(\mathrm{R}=0.18)$, there was little or no effect $(\mathrm{R}<0.6)$. For the second canonical pair, there were no significant differences between the attributes of $\mathrm{CI}$ and GRSP content (CII) in the soils of Irauçuba-CE.

Calcium $\left(\mathrm{Ca}^{2+}\right)$ was the variable from CI that obtained highest correlation with the variables from CII in the three studied areas (Table 5), thus evidencing in the present study its importance in the production of GRSP. Andrade et al. (1995), studying the coffee crop in Purple Latosol in the Paraná state, observed that the mycorrhizal colonization increased with the addition of limestone. In the present study, $\mathrm{Ca}^{2+}$ showed high correlation (0.86) with the contents of both GRSP types, but its highest correlation occurred with GRSP $\mathrm{T}_{\mathrm{T}}$. Wu et al. (2014) claim that $\mathrm{Ca}^{2+}$ may participate in the establishment of arbuscular mycorrhizae, promoting growth of hyphae and spores that, with the consequent decomposition of these fungal structures, will lead to the formation of GRSP, a fact that may clarify the strong correlation between calcium and the protein produced by glomalean fungi. Nevertheless, such results are controversial and many other authors have demonstrated negative correlation or absence of correlation between this protein and the contents of $\mathrm{Ca}^{2+}$ (Lovelock et al., 2004; Mergulhão, 2006). 
Table 5. Canonical correlations and canonical pairs between the characteristics of the sets $\mathrm{CI}\left(\mathrm{pH}^{\mathrm{C}} \mathrm{Ca}^{2+}, \mathrm{Mg}^{2+}\right.$, $\mathrm{Al}^{3+}, \mathrm{P}, \mathrm{OC}, \mathrm{N}, \mathrm{AS}$ and $\left.\mathrm{SD}\right)$ and $\mathrm{CII}\left(\mathrm{GRSP}_{\mathrm{EE}}\right.$ and $\left.\mathrm{GRSP}_{\mathrm{T}}\right)$ referring to the 21 studied points

\begin{tabular}{|c|c|c|c|}
\hline \multirow{3}{*}{ Sets } & \multirow{3}{*}{ Attributes } & \multicolumn{2}{|c|}{ Canonical Pairs } \\
\hline & & 1 & 2 \\
\hline & & \multicolumn{2}{|c|}{ Canonical Correlations } \\
\hline \multirow[t]{9}{*}{$\mathrm{CI}$} & $\mathrm{pH}$ & -0.701 & 0.078 \\
\hline & $\mathrm{Ca}^{2+}$ & -0.864 & 0.095 \\
\hline & $\mathrm{Mg}^{2+}$ & -0.714 & 0.305 \\
\hline & $\mathrm{Al}^{3+}$ & 0.456 & 0.029 \\
\hline & $P$ & -0.082 & -0.137 \\
\hline & $\mathrm{OC}$ & -0.842 & 0.063 \\
\hline & $\mathrm{N}$ & -0.847 & 0.053 \\
\hline & AS & -0.618 & -0.082 \\
\hline & SD & 0.180 & 0.119 \\
\hline \multirow[t]{5}{*}{ CII } & $\mathrm{GRSP}_{\mathrm{EE}}$ & -0.942 & -0.335 \\
\hline & $\mathrm{GRSP}_{\mathrm{T}}$ & -0.998 & 0.055 \\
\hline & R-Canonical & $0.973 * *$ & $0.835^{\mathrm{n} \mathrm{s}}$ \\
\hline & Chi-square & 55.670 & 16.094 \\
\hline & DF & 20 & 9 \\
\hline
\end{tabular}

Note. $\mathrm{P}=$ phosphorus; $\mathrm{Al}^{3+}=$ aluminum; $\mathrm{Mg}^{2+}=$ magnesium; $\mathrm{Ca}^{2+}=$ calcium; $\mathrm{pH}=$ potential of hydrogen; OC $=$ organic carbon; $\mathrm{N}=$ nitrogen; $\mathrm{AS}=$ aggregate stability; $\mathrm{SD}=$ spore density; $\mathrm{DF}=$ degrees of freedom; $* *, *, \mathrm{~ns}$, significant at $0.01,0.05$ probability levels and not significant, respectively. (1) Canonical correlations $\geq 0.6$ were considered as significant for comparison purposes.

In decreasing order of correlation, $\mathrm{N}$ and organic carbon were the variables that, after $\mathrm{Ca}^{2+}$, showed the highest correlations (0.84) with both GRSP fractions (Table 5). However, regarding the two GRSP fractions, GRSP showed the highest correlation with the variables $\mathrm{N}$ and organic $\mathrm{C}$, which can probably be explained by the fact that this fraction is more stable and, consequently, has a reduced decomposition rate, which leads to higher contents of these two elements in the soil (Rilling et al., 2001; Steinberg \& Rilling, 2003).

The positive correlation of the variables $\mathrm{N}$ and organic $\mathrm{C}$ with both GRSP fractions can be attributed to the fact that this glycoprotein has in its chemical composition considerable amounts of carbon and nitrogen, possibly containing values from 28 to $45 \%$ of $\mathrm{C}$ and from 0.9 to $7.3 \%$ of $\mathrm{N}$, thus constituting a substantial reservoir of $\mathrm{C}$ and $\mathrm{N}$ in the soils (Rilling et al., 2003; Lovelock et al., 2004; Nichols \& Wright, 2006). Organic C is one of the most consistent indicators of GRSP content in the ecosystems (Sousa et al., 2011). Positive correlations between organic C and GRSP have been demonstrated (Bird et al., 2002; Franzluebbers, 2000). Lovelock et al. (2004), working with two soils of Costa Rica, observed that the contents of $\mathrm{C}$ and $\mathrm{N}$ in the GRSP corresponded to approximately 3.2 and $5 \%$ of the total reservoir of $\mathrm{C}$ and $\mathrm{N}$ of these soils. Similar results were obtained by Rilling et al. (2001).

The $\mathrm{pH}$ was another variable from the set CI that showed positive correlation $(0.70)$ with both GRSP fractions of set CII (Table 5). Fungi tend to predominate in acid soils and, since GRSP is produced by AMF, it is expected to find higher production of this protein in acid soils (Haddad \& Sarkar, 2003). Possibly, under the condition of acid $\mathrm{pH}$, there is greater preservation of GRSP, because this condition is not favorable to the presence and activity of microorganisms that decompose this protein (Lima et al., 2013). Some authors, however, have observed negative correlation between glomalin contents and soil pH (Rilling et al., 2003; Haddad \& Sarkar, 2003; Mergulhão, 2006).

Various studies have demonstrated that GRSP content is highly correlated with soil aggregate stability, consequently promoting improvements in the edaphic structuration and quality, thus contributing to the reduction in the risks of erosion (Wright \& Upadhyaya, 1998; Wright \& Anderson, 2000; Wright et al., 2007). In the present study, there was a positive correlation (0.61) between both GRSP fractions and aggregate stability (Table 5).

The correlation between GRSP and aggregate stability may be attributed to the recalcitrance and hydrophobicity of this protein, working as an organic ligand, helping in the fixation of particulate material in the soil, besides favoring the formation and improvement in the stability of aggregates (Purin, 2005; Wright et al., 1996). Nobre et al. (2015), studying contents of soil organic carbon and GRSP in different phytophysiognomies in the 
Caatinga biome, in the Araripe Plateau (CE), also found positive correlation between the protein produced by the AMF and the stability of soil aggregates.

On the other hand, the variables from set $\mathrm{CI}, \mathrm{Al}^{3+}(\mathrm{R}=0.45), \mathrm{SD}(\mathrm{R}=0.18)$ and $\mathrm{P}(\mathrm{R}=0.08)$, showed low correlation with the variables from set $\mathrm{CII}\left(\mathrm{GRSP}_{\mathrm{EE}}\right.$ and $\left.\mathrm{GRSP}_{\mathrm{T}}\right)$, because the respective variables $\mathrm{Al}^{3+}, \mathrm{SD}$ and $\mathrm{P}$ obtained canonical correlations with values below 0.6 in modulus. According to Santos (2010), variables with values $<0.6$ are the ones that least contribute to explaining the correlations between the variables of the formed sets.

\section{Conclusions}

The contents of the glomalin-related soil protein $\left(\mathrm{GRSP}_{\mathrm{EE}}\right.$ and $\left.\mathrm{GRSP}_{\mathrm{T}}\right)$ of the native forest were higher than those found in the areas of exclusion and overgrazing, proving that the intense degradation of these areas contributed to the decrease in GRSP content.

The highest correlations were observed between calcium, nitrogen and organic carbon $\left(\mathrm{Ca}^{2+}, \mathrm{N}\right.$ and $\left.\mathrm{OC}\right)$ and both glomalin-related soil protein fractions $\left(\mathrm{GRSP}_{\mathrm{EE}}\right.$ and $\left.\mathrm{GRSP}_{\mathrm{T}}\right)$, indicating that these elements of soil influence indirectly the GRSP content of the soil.

The GRSP content, associated with other edaphic attributes, contributes to discriminating the quality and monitoring Caatinga areas with different levels of soil degradation in Irauçuba-CE.

\section{References}

Andrade, D. S., et al. (1995). Atividade microbiana em função da calagem em um solo cultivado com cafeeiro. Revista Brasileira de Ciência do Solo, 19(2), 191-196.

Barto, E. K., et al. (2010). Contributions of biotic and abiotic factors to soil aggregation across a lande use gradient. Soil Biology and Biochemistry, 42(12), 2316-2324. https://doi.org/10.1016/j.soilbio.2010.09.008

Batista, Q. R., et al. (2009). Bioqualidade de área degradada pela extração de argila, revegetada com Eucalyptus spp. e sabiá. Revista Caatinga, 22(1), 146-154. Retrieved from http://www.redalyc.org/html/2371/237117 576026

Bird, S. B., et al. (2002). Spatial heterogeneity of aggregate stability and soil carbon in semi-arid rangeland. Environmental Pollution, 116(3), 445-455. https://doi.org/10.1016/S0269-7491(01)00222-6

Bradford, M. M. (1976). A rapid and sensitive method for the quantification of microgram quantities of protein utilizing the principle of protein-dye binding. Analytical Biochemistry, 72(1-2), 248-254. https://doi.org/ 10.1016/0003-2697(76)90527-3

Caproni, A. L. (2003). Ocorrência de fungos micorrízicos arbusculares em áreas re \pm orestadas remanecentes da mineração de bauxita em Porto Trombetas, PA. Pesquisa Agropecuária Brasileira, 38(12), 1409-1418. https://doi.org/10.1590/S0100-204X2003001200007

Cardozo Jr., F. M. (2011). Dinâmica e biodiversidade de fungos micorrízicos arbusculares em diferentes áreas sob influência do processo de desertificação em Gilbués-Brasil (Dissertação, Mestrado em Agronomia, Universidade Federal do Piauí, Piauí, Gilbués).

Carrenho, R., Trufem, S. F. B., \& Bononi, V. L. R. (2001). Fungos micorízicos arbusculares em rizosferas de três espécies de fitobiontes instaladas em área de mata ciliar revegetada. Acta Bot. Bras., 15(1), 115-124. https://doi.org/10.1590/S0102-33062001000100011

Driver, J. D., Holben, W. E., \& Rilling, M. C. (2005). Characterization of glomalin as a hyphal wall component of arbuscular mycorrhizal fungi. Soil Biology and Biochemistry, 37(1), 101-106. https://doi.org/10.1016/ j.soilbio.2004.06.011

Drumond, M. A., Kiill, L. H. P., Lima, P. C. F., Oliveira, M. C., Oliveira, V. R., Albuquerque, S. G., ... Cavalcante, J. (2000). Estratégias para o uso sustentável da biodiverdidade da caatinga. In Seminário para avaliação e identificação de ações prioritárias para a conservação, utilização sustentável e repartição de benefícios da biodiversidade do bioma Caatinga. Embrapa/Cpatsa, UFPE e Conservation International do Brasil, Petrolina.

EMBRAPA (Empresa Brasileira de Pesquisa Agropecuária). (1997). Manual de métodos de análise de solo (p. 212). Rio de Janeiro: EMBRAPA. 
Franke, M., \& Morton, J. B. (1994). Ontogenetic comparisons of arbuscular mycorrhizal fungi Scutellospora heterogama and Scutellospora pellucida: Revision of taxonomic character concepts, species descriptions, and phylogenetic hypotheses. Canadian Journal of Botany, 72(1), 122-134. https://doi.org/10.1139/b94-017

Franzluebbers, A. J., Wright, S. F., \& Stuedemann, J. A. (2000). Soil aggregation and glomalin under pastures in the southern Piedmont USA. Soil Science Society of America Journal, 64(3), 1018-1026. https://doi.org/ 10.2136/sssaj2000.6431018x

Gee, G. W., \& Bauder, J. W. (1986). Particle-Size analysis. In A. Klute (Ed.), Methods of soil Analysis (pp. 383-411, Agronomy Monography, 9). Madison: American Society of Agronomy, Soil Science Society of America.

Haddad, M. J., \& Sarkar, D. (2003). Glomalin, a newly discovered component of soil organic matter: Part II Relationship with soil properties. Environmental Geosciences, 10(3), 99-106. https://oi.org/10.1306/ eg.05020303005

IBGE (Instituto Brasileiro de Geografia e Estatística). (2010). Canal Cidades: Lavouras temporária, permanente e pecuária e o PIB dos munícipios.

Lima, F. S., Soares, A. C. F., \& Sousa, C. S. (2013). Ocorrência e atividade de fungos micorrízicos arbusculares em plantios de eucalipto (Eucalyptus sp.) no litoral norte da Bahia, Brasil. Revista Árvore, 37(2), $245-255$. https://doi.org/10.1590/S0100-67622013000200006

Lipper, L., Dutilly-Diane, C., \& Mccarthy, N. (2010). Supplying Carbon Sequestration from West African Rangelands: Opportunities and Barriers. Rangeland Ecology and Management, 63(1), $155-166$. https://doi.org/10.2111/REM-D-09-00009.1

López-Merino, L., et al. (2015). Glomalin accumulated in seagrass sediments reveals past alterations in soil quality due to land-use change. Global and Planetary Change, 133(33), 87-95. https://doi.org/10.1016/ j.gloplacha.2015.08.004

Loss, A., et al. (2009). Atributos químicos do solo e ocorrência de fungos micorrízicos sob áreas de pastagem e sistema agroflorestal, Brasil. Acta Agronómica, 58(2), 91-95.

Lovelock, C. E., et al. (2004). Soil stocks of glomalin produced by arbuscular mycorrhizal fungal across a tropical rain forest landscape. Journal of Ecology, 92(2), 278-287. https://doi.org/10.1111/j.0022-0477.2004. 00855.x

Mclellan, A. J., Fitter, A. H., \& Law, R. (1995). On decaying roots, mycorrhizal colonisation and the design of removal experiments. Journal of Ecology, 83(2), 225-230. https://doi.org/10.2307/2261561

Mekuria, W., et al. (2007). Effectiveness of exclosures to restore degraded soils as a result of overgrazing in tigray. Journal of Arid Environments, 69(2), 270-284. https://doi.org/10.1016/j.jaridenv.2006.10.009

Mergulhão, A. C. E. S. (2006). Aspectos ecológicos e moleculares de fungos micorrízicos arbusculares (p. 152 , Tese Doutorado em Ciências Biológicas, Universidade Federal de Pernambuco).

Moreira-Souza, M., \& Cardoso, E. J. B. N. (2002). Dependência micorrizica de Araucaria angustifolia (Bert.) O. Ktze. sob doses de fósforo. Rev. Bras. Ci. Solo, 26, 905-912, https://doi.org/10.1590/S0100-068320020 00400007

Moreira-Souza, M., Trufem, S. F. B., Costa-Gomes, S. M., \& Cardoso, E. J. B. N. (2004). Arbuscular mycorrhizal fungi associated with Araucaria angustifolia (Bert.) O. Ktze. Mycorrhiza, 13, 211-215. https://doi.org/10.1007/s00572-003-0221-1

Nichols, K. A., \& Wright, S. F. (2006). Carbon and nitrogen in operationally defined soil organic matter pools. Biology \& Fertility of Soils, 43(2), 215-220. https://doi.org/10.1007/s00374-006-0097-2

Nobre, C. P., et al. (2015). Agregação, glomalina e carbono orgânico na chapada do Araripe, Ceará, Brasil. Revista Caatinga, 28(1), 138-147.

Pei, S., Fu, H., \& Wan, C. (2008). Changes in soil properties and vegetation following exclosure and grazing in degraded Alxa desert steppe of Inner Mongolia, China. Agriculture, Ecosystems and Environment, 124(1-2), 33-39. https://doi.org/10.1016/j.agee.2007.08.008

Peng, S. L., Guo, T., \& Liu, G. C. (2013). The effects of arbuscular mycorrhizal hyphal networks on soil aggregations of purple soil in southwest China. Soil Biology and Biochemistry, 57, 411-417. https://doi.org/ 10.1016/j.soilbio.2012.10.026 
Purin, S. (2005). Fungos micorrizicos arbusculares: Atividade, diversidade e aspectos funcionais em sistemas de produção de maçã (p. 147, Dissertação de Mestrado, Florianópolis, Universidade do Estado de Santa Catarina).

Purin, S., \& Rilling, M. C. (2007). The arbuscular mycorrhizal fungal protein glomalin: Limitations, progress, and a new hypothesis for its function. Pedobiologia, 51(2), 123-130. https://doi.org/10.1016/j.pedobi.2007. 03.002

Rillig, M. C., et al. (2001). Large contribution of arbuscular mycorrhizal fungi to soil carbon pools in tropical forest soils. Plant and Soil, 233(2), 167-177. https://doi.org/10.1023/A:1010364221169

Rilling, M. C., Maestre, F. T., \& Lamit, L. J. (2003). Microsite differences in fungal hyphal length, glomalin, and soil aggregate stability in semiarid Mediterranean steppes. Soil Biology and Biochemistry, 35(9), 1257-1260. https://doi.org/10.1016/S0038-0717(03)00185-8

Rosier, C. L., Hoye, A. T., \& Rillig, M. C. (2006). Glomalinrelated soil protein: Assessment of current detection and quantification tools. Soil Biology \& Biochemistry, 38(8), 2205-2211. https://doi.org/10.1016/ j.soilbio.2006.01.021

Schneidr, J., et al. (2011). Influência de diferentes sistemas de manejo e calagem em experimento de longa duração sobre fungos micorrizicos arbusculares. Ciência agrotecnologia, 35(4), 701-9. https://doi.org/ 10.1590/S1413-70542011000400008

Silva, C. F., et al. (2010). Atividade de fungos micorrízicos arbusculares em dunas litorâneas impactadas por mineração. Reunião brasileira de fertilidade do solo e nutrição de plantas, 29; reunião brasileira sobre micorrizas, 13; simpósio brasileiro de microbiologia do solo, 11; reunião brasileira de biologia do solo, 8 . Fontes de nutrientes e produção agrícola: Modelando o futuro: Anais... Viçosa: Sociedade Brasileira de Ciência do Solo.

Sousa, C. S., et al. (2011). Influências da temperatura de armazenamento e de extratores na determinação de glomalina em solos Paraibanos. Revista Ciência Agronômica, 42(4), 837-841. https://oi.org/10.1590/ S1806-66902011000400003

Sousa, C. S., et al. (2012a). Glomalina: Características, produção, limitações e contribuição nos solos. Semina: Ciências Agrárias, 336(6), 3033-3044. https://doi.org/10.5433/1679-0359.2012v33n6Supl1p3033

Sousa, F. P. (2009). Degradação de solos por atividades agropastoris em áreas sob processo de desertificação: O caso de Irauçuba, Ceará (89 f., Dissertação de mestrado em solos e nutrição de plantas, Universidade Federal do Ceará).

Sousa, F. P., et al. (2012b). Carbon and nitrogen in degraded Brazilian semi-arid soils undergoing desertification. Agriculture, Ecosystems and Environment, 148, 11-21. https://doi.org/10.1016/j.agee.2011.11.009

Souza, F. A., et al. (2010). Classificação e taxonomia de fungos micorrízicos arbusculares e sua diversidade e ocorrência no Brasil. In J. O. Siqueira, et al. (Eds.), Micorrizas: 30 anos de pesquisa no Brasil (pp. 15-73). Lavras: Editora UFLA.

Steinberg, P. D., \& Rillig, M. C. (2003). Differential decomposition of arbuscular mycorrhizal fungal hyphae and glomalin. Soil Biology and Biochemistry, 35(1), 191-194. https://doi.org/10.1016/S0038-0717(02)00249-3

Sylvia, D. M., \& Jarsfer, A. G. (1992). Sheared-root inocula of vesicular-arbuscular mycorrhizal fungi. Applied Environmental Microbiology, 58, 229-232.

Sylvia, D. M., \& Williams, S. E. (1992). Vesicular-arbuscular mycorrhizae and environmental stress. In G. J. Bethlenfalvay, \& R. G. Linderman (Eds.), Mycorrhizae in sustainable agriculture (pp. 101-124). Madison: ASA Special Publication.

Vaidya, S., et al. (2011). Substrate induced conformational changes occur in all cleaved forms of caspase-6. Journal of Molecular Biology, 406(1), 75-9. https://doi.org/10.1016/j.jmb.2010.11.031

Valone, T. J., \& Sauter, P. (2005). Effects of long-term cattle enclosure on vegetation and rodents at a desertified arid grassland site. Journal of Arid Environments, 61(1), 167-170. https://doi.org/10.1016/j.jaridenv.2004. 07.011

Wright, S. F., \& Anderson, R. L. (2000). Aggregate stability and glomalin in alternative crop rotations for the central Great Plains. Biology and Fertility of Soils, 31(3), 249-253. https://doi.org/10.1007/s0037400 50653 
Wright, S. F., \& Upadhyaya, A. (1996). Extraction of an abundant and unusual protein from soil and comparison with hyphal protein of arbuscular mycorrhizal fungi. Soil Science, 161(9), 575-586. https://doi.org/10.1097/ 00010694-199609000-00003

Wright, S. F., \& Upadhyaya, A. (1998). A survey of soils for aggregate stability and glomalin, a glycoprotein produced by hyphae of arbuscular mycorrhizal fungi. Plant and Soil, 198(1), 97-107. https://doi.org/ 10.1023/A:1004347701584

Wright, S. F., et al. (1996). Timecourse study and partial characterization of a protein on hyphae of arbuscular mycorrhizal fungi during active colonization of roots. Plant and Soil, 181(2), 193-203. https://doi.org/ 10.1007/BF00012053

Wright, S. F., Green, V. S., \& Cavigelli, M. A. (2007). Glomalin in aggregate size classes from three different farming systems. Soil \& Tillage Research, 94(2), 546-549. https://doi.org/10.1016/j.still.2006.08.003

Wu, Q. S., et al. (2014). Calcium and Calmodulin Involve in Mycorrhizal and Root Development in Trifoliate Orange Colonized by Rhizophagus intraradices. Notulae Botanicae Horti Agrobotanici, 42(2), $380-385$. https://doi.org/10.15835/nbha4229635

XLSTAT. (2014). XLSTAT 2013 add-in for Excel (Trial Version). New York. Retrieved March 25, 2014, from http://wwwxlstat.com

Zhao, H. L., et al. (2007). Shrub facilitation of desert land restoration in the Horqin Sand Land of Inner Mongolia. Ecological Engineering, 31(1), 1-8. https://doi.org/10.1016/j.ecoleng.2007.04.010

\section{Copyrights}

Copyright for this article is retained by the author(s), with first publication rights granted to the journal.

This is an open-access article distributed under the terms and conditions of the Creative Commons Attribution license (http://creativecommons.org/licenses/by/4.0/). 